\title{
Ecumenism in Liturgy?
}

\section{Changes in Finnish Orthodox Liturgical Texts Stimulated by Co-Existence with Lutherans}

\author{
Damaskinos OlKINUORA*
}

The Finnish Orthodox Church forms a small minority in a predominantly Lutheran country. Since the 1950s, some changes in liturgical texts have occurred because of this Lutheran presence. This paper discusses three of them: the addition "and all Christians" in the Great Entrance, the addition "through your intercessions" in the prayer formula "Most-holy Theotokos, save us", and the commemoration of "our Bishop Irja" during the visits of the Lutheran bishop of Helsinki, Irja Askola, in the Uspensky Cathedral of Helsinki in 2015. The author proposes that the two first cases took place in order to reconcile the Orthodox population with their Lutheran surroundings by the commemoration of their non-Orthodox friends and relatives in the liturgy, on one hand, and to explain dogmatic thought that is foreign to Lutheran mentality, on the other. The additions, however, pose theological problems and should not be used as such.

Keywords: Finland, commemoration, ecumenism, liturgy, Lutheranism, Orthodoxy, prayer, Theotokos.

Finland has often been quoted as a model example for the inter-denominational relationship between the two state-recognized churches, the Evangelical Lutheran Church of Finland and the Orthodox Archbishopry of Finland, an autonomous part of the Ecumenical Patriarchate. This narrative, even though widespread in both scholarly and ecumenical circles, is not without problems: not many decades ago, hostile attitudes against the other denomination were still common in both churches. Indeed, Tarja Raninen-Siiskonen has stated that "the concept of the integrating co-existence, in the spirit of mutual respect and co-operation, has been repeated in literature so often that it has become a crystallized narrative".

However, history is more nuanced than this. The Finnish Orthodox population, a result of medieval Novgorodian missionary work, had traditionally lived in the eastern parts of the country: it was a border zone be-

\footnotetext{
* Monk Damaskinos (Olkinuora) of Xenophontos, University Teacher, Systematic Theology and Patristics, School of Theology, University of Eastern Finland, Address: Kirkkokatu 35b C 27, 80100 Joensuu, Finland, e-mail: munkki.damaskinos@ort.fi

1 Tarja Raninen-Siiskonen, Vieraana omalla maalla: tutkimus karjalaisen siirtoväen muistelukerronnasta, Helsinki, Suomalaisen kirjallisuuden seura 1998, p. 98.
} 
tween Sweden and Russia before the Finnish independence. After Finland became a Grand Duchy of the Russian empire in 1809, Orthodox churches for the needs of the Russian army were built until 1917 in Western Finland. World War II led to the evacuation of some 400,000 Finnish nationals (from 1939 onwards) from the areas that were taken over by the Soviet Union. This lead to the loss of about $95 \%$ of the property of the Orthodox Church, and a great part of the Orthodox population had to move to areas where Orthodoxy was virtually unknown. Often, the refugees were treated with suspicion. In 1945, a moment after the two wars with the Soviet Union and a less extensive one with the Germans had ended, Hannu Timperi provided us a description of common Lutheran views on the Orthodox church: the latter were seen as non-nationalists and superstitious because of the "worshipping" of images and saints (indeed, even today, the mocking word "image worshippers" is used among more hard-line Protestants). ${ }^{2}$

It must be borne in mind that a part of the Orthodox population spoke Russian or Karelian (a minor language of the Fenno-Ugric group, closely related to Finnish but rich in Russian loan-words and "Russian-like" phonems) as their mother tongue, even if they were of Finnish nationality, while the rest of the population spoke mainly Finnish and Swedish. The use of Russian names and loan-words and Old Church Slavonic as one of the liturgical languages, even among the Finnish-speaking Orthodox, did not please the post-war society, especially because of the past image of Orthodox churches built for the Russian army as a symbol of foreign power: indeed, many Orthodox were obliged to convert into Lutheranism and Finnicize their names, in order to become more integrated into the society. During the wars, the number of registered Orthodox believers in the country exceeded 80000 , but after the wars there was a constant decrease until early 1990s, when the number of believers was closer to 55,000. In 2016, the church had 60,566 members. ${ }^{3}$

Despite the negative public atmosphere, the Orthodox population mainly aimed at peaceful co-existence with the Lutheran majority, ${ }^{4}$ even

2 Hannu Timperi, “Ortodoksinen kirkko luterilaisten silmissä”, in: Aamun koitto 21/1945, p. 321. For further descriptions of the historical setting, see Helena Kupari, Sense of Religion: The Lifelong Religious Practice of the Evacuee Karelian Orthodox Women in Finland, Helsinki, University of Helsinki 2015.

3 https://www.ort.fi/sites/default/files/liitteet/Jaana\%20Prada/Väestötilasto2016julkaisu. pdf, viewed on 27th February 2017. See also diagrams depicting the demographic changes in the Finnish Orthodox Church since 1925: https://www.ort.fi/sites/default/files/liitteet/ Jaana\%20Mikkonen/jasenmaaramuutokset.pdf.

4 Opions on remaining in good relations with the Lutherans are expressed, among others, by the famous Finnish archpriest Sergei Okulov (1853-1940); see Teuvo Laitila, Uskon luotsi: Sergei Okulov Suomen ortodoksien vaiheissa, Kuopio, Aamun koitto 2004, p. 248-254. After the war, the 
though some exceptions existed: still in the 1990s, it was discussed in the Finnish Orthodox press whether or not non-Karelian converts could be considered "genuine" Orthodox, an idea that reflects a strong differentiation between the Orthodox and Lutheran population and the halfheartedness to open up to the predominantly Lutheran society. Today, however, the relations between the two churches are extremely positive. The Lutheran Church has adopted Orthodox elements in its liturgical practice(s), and active ecumenical dialogue takes place on a hierarchical, theological and ground level. A visible sign of the co-operation of the two churches is the School of Theology at the University of Eastern Finland, a university department that consists of a Western and an Orthodox program in academic theology.

A subject less studied is the influence of living as a minority among a Lutheran majority in the liturgical texts used by the Orthodox church. The present paper draws attention to some additions to and omissions of traditionally accepted Orthodox liturgical texts that can be seen as a result of interaction with the Lutheran majority. Three cases shall be discussed in a chronological order, presenting the historical and ideological context, as well as written sources related with the cases. All three instances are, according to our hypothesis, unique for the Finnish Orthodox Church and have been motivated by the presence of the Lutheran majority. In the end, I shall provide a more interpretative reflection of these cases as a whole.

A problem in all three cases is the lack of documentation. Only the first case is attested to in printed service books, but the last two are a purely oral practice: in the last case, the study is based mainly on on-line sources. However, a more detailed study with documented source material would require extensive field work in Finnish Orthodox parishes and remains yet a desideratum.

\section{“Orthodox Christians" or "all Christians": who should be commem- orated in the liturgy?}

The only one of our three case studies that has received scholarly attention is the oldest one. In 2015, Mikael Sundkvist and Pekka Metso published a paper on the Finnish variant of the petition read in the Great Entrance of the divine liturgy, together with the ecclesiological problems it causes. ${ }^{5}$ They provide a historical overview of this formula and its first appearance in the liturgy manual of 1954 , while the most common practice

relations between the churches were not particularly warm, as professor Heikki Kirkinen notes in his report on the ecumenical activities of the Orthodox Church: see Heikki Kirkinen, "Ortodoksinen kirkko ekumeenisessa työssä", in: Aamun koitto (11-12/1957), p. 137-138.

5 Pekka Metso, Mikael Sundkvist, "Millaista ekklesiologiaa ”...ja kaikkia kristittyjä” -lisäys edustaa? Suuren saaton muistelun suomalainen käytäntö”, in: Ortodoksia 54 (1/2015), p. 121-134. 
today is based on Archbishop Paul's liturgy rendition from 1980. In the Great Entrance, the priest ends the commemoration of the local bishop with the phrase "all you right-believing [i.e. Orthodox] Christians" (in Finnish, "kaikkia teitä oikeauskoisia kristittyjä"), while the deacon continues "and all Christians always, now and ever, and from eternity to eternity" (in Finnish, "ja kaikkia kristittyjä alati, nyt ja aina ja iankaikkisesta iankaikkiseen"). ${ }^{6}$ The authors hypothesize that the addition was an ecumenical outreach in the difficult situation the Orthodox refugees experienced in post-war Finland. ${ }^{7}$

Commemorating non-Orthodox Christians in the Great Entrance, which is characteristically a eucharistic procession, is however problematic from an ecclesiological point of view: it would imply that the non-Orthodox are also considered to be in communion with the Orthodox church. The only exception in such commemoration, so the authors claim, is the ruler of the country in question. ${ }^{8}$ Finally, Metso and Sundkvist suggest some changes in order to loosen up the ecclesiological tensions provoked by the addition: they propose an addition on behalf of "all Christians" in the petitions preceding the Cherubic Hymn, and would prefer a more neutral formula "may the Lord remember you/us all" in the Great Entrance, in order to avoid the juxtaposition between "Orthodox" and "all" Christians."

The authors do not, however, join the wider discussion of similar additions or omissions in other liturgical texts. More exactly, there is a tendency in the $21^{\text {st }}$ century publications to avoid the expression "Orthodox Christians", perhaps because of this problematic commemoration in the Great Entrance. A new Horologion was published in 2000, edited by Aleksander (Arimo) Nyström. ${ }^{10}$ The text sometimes omits the combination "Orthodox Christians" and replaces it with "all Christians", sometimes uses them both. The former is the case in the verse of the Vespers and Matins: "Establish, O God, holy Orthodox faith and all Christians now and forever" (in Finnish, "Vahvista, Jumala, pyhää ortodoksista uskoa ja kaikkia kristittyjä iäti ja iankaikkisesti”) ${ }^{11}$ and in the concluding polychronion of main services, where the final phrase is "and to all Christians [God grant many years]" (in Finnish, "ja kaikille kristity-

\footnotetext{
${ }^{6}$ Ibidem, p. 121-122. The English translations in this article are by the author, and they aim at a literary translations from the Finnish text, in order to convey nuances and deviations from the original Greek.

7 Ibidem, p. 123-124.

8 Ibidem, p. 124-127.

9 Ibidem, p. 127-128.

10 Aleksander Nyström (ed.), Rukouskirja Orologion, Jyväskylä, Ortodoksisen kirjallisuuden julkaisuneuvosto 2000 .

11 Ibidem, p. 311.
} 
ille"). ${ }^{12}$ In the concluding petitions of Compline and Midnight Office, both are used: "Let us pray for faithful Orthodox Christians and all Christians" (in Finnish, "Rukoilkaamme uskovien ortodoksisten kristittyjen ja kaikkien kristittyjen puolesta"). ${ }^{13}$

Similar changes were included in the new priest's liturgy manual, accepted for test use by the bishops' synod of the Finnish Orthodox Church in $2001 .{ }^{14}$ In the petitions for the departed before the Cherubic Hymn, the book is explicit in praying only for the departed Orthodox Christians, ${ }^{15}$ but the petition of the Great Entrance corresponds to the earlier practice and includes "all Christians". ${ }^{16}$ The polychronion omits the word "Orthodox" and ends in "and to all Christians" (in Finnish, "ja kaikille kristityille"). ${ }^{17}$ The reception of these books, however, was limited: the Horologion is widely used in the reading of the Hours, but only partly for Vespers and Matins. ${ }^{18}$ The liturgy manual is, as far as I am aware, not in active use in any parish.

A more recent epilogue to this change took place less than a decade ago, when a decree by Metropolitan Ambrose, dated on April 21, 2009, was distributed in an encyclical to the priests and cantors of the diocese of Helsinki: similar instructions have not been given in the two other dioceses, Oulu and Karelia. ${ }^{19}$ The letter includes three orders. Firstly, the word "right-believing" (the literary Finnish translation of the word "Orthodox", "oikeauskoinen") is to be replaced with the word "Orthodox" (in Finnish, "ortodoksinen") or, occasionally, with "all Christians" (even though it is not specified where "Orthodox" should be preferred); secondly, the epistle readings must start with the words "brothers and sisters" (in Finnish, "veljet ja sisaret"); thirdly, the ending polychronion sung in the

12 Ibidem, p. 312.

13 Ibidem, p. 347.

14 Pyhien isiemme Johannes Krysostomoksen ja Basileios Suuren liturgia, Hämeenlinna, Ortodoksisen kirjallisuuden julkaisuneuvosto 2012.

15 Ibidem, p. 54-56.

16 Ibidem, p. 67.

17 Ibidem, p. 110.

18 The cases we noted are usually drawn from other standard service books: the polychronion and the petition "Establish, O God..." are usually sung from Sunnuntaivigilia, Pieksämäki, Ortodoksisen kirjallisuuden julkaisuneuvosto 1986, p. 78-82, while the concluding petitions of Compline and Midnight Office are normally read from the priest's manual: Ehtoo- ja aamupalvelus jubla- ja arkipäivinä, Pieksämäki, Ortodoksisen kirjallisuuden julkaisuneuvosto 1956 , p. 121.

19 The encyclical is titled as "Jumalanpalvelusohjeita Helsingin hiippakunnassa" "Liturgical instructions in the diocese of Helsinki") and signed by Metropolitan Ambrose. It has not been published. 
services must end in the phrase "and to all Christians" instead of "and to all Orthodox Christians" (in Finnish: "kaikille kristityille" instead of "kaikille oikeauskoisille kristityille"), a practice that corresponds to the 2000 Horologion publication.

In addition, the encyclical included two recommendations, implying that their authority is not as binding as the three changes above. These are the abbreviated form "and eternally" instead of "from eternity to eternity" (in Finnish, "iankaikkisesti" instead of "iankaikkisesta iankaikkiseen"), in the ending of the standard doxology "Glory to the Father..." ( $\Delta$ ó $\xi \alpha$ Патрі kaì Yi $\tilde{\omega} . .$.$) and in the closings of prayers. Also, the references to "holy fathers"$ in prayers should be replaced by the more gender-neutral "holy persons": the encyclical provides the example of a standard blessing "Through the prayers of our holy fathers..." ( $\left.\Delta \mathrm{l}^{\prime} \varepsilon \dot{v} \chi \tilde{\omega} v \ldots ..\right)$.

The encyclical seems to imply a few aims. There is a direction towards gender neutrality through the inclusion of "brothers and sisters" in the epistles, but it is not semantically completely arbitrary: the standard Greek initial ả $\delta \varepsilon \lambda \varphi o i ́$ can refer either to a completely masculine audience or a mixed audience, consisting of both men and women. This change seems justified.

The other gender-related recommendation, however, is more arbitrary. The petition "Through the prayers..." $\left(\Delta \mathrm{l}^{\prime} \varepsilon v \chi \tilde{\omega} \tilde{v}\right.$...) is not related to the saints of the church, but the present fathers of the praying community. For this reason, when the bishop is present, the formula is changed into

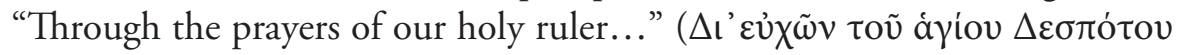
$\dot{\eta} \mu \tilde{\omega} v . .$.$) or in monasteries, when the abbot is present, into "Through the$

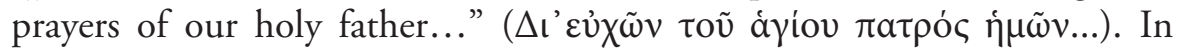
some sources it is even suggested that in female monasteries the formula should be changed into "Through the prayers of our holy mothers...", or "Through the prayers of our holy mother...", respectively. ${ }^{20}$

The change from "right-believing" to "Orthodox" and "all Orthodox Christians" to "all Christians" seem to have an ecumenist tendency, instead. The first change avoids the Finnicized form, more concretely understood, preferring a more institutionalized Greek term "Orthodox"; it must be noted that in Finnish the word "Orthodox" does not carry the meaning of "rightful" as strongly as in English, but is a more technical term that refers primarily to the Orthodox population. The second change seems to be embracing the Lutheran majority of the country by not emphasizing the idea of "correct faith" being found exclusively in the Orthodox Church.

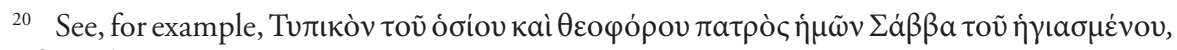

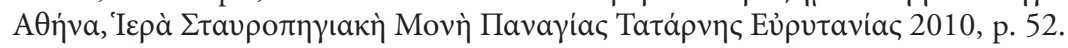


The reception of the encyclical has varied. There are several churches where the older form "all Orthodox Christians" is kept, ${ }^{21}$ while some have used the reformed formula "all Christians" even before the encyclical. ${ }^{22}$ In the new liturgy hymnal published in 2011, accepted by the bishop's synod of the Finnish church, the older form "all Orthodox Christians" is preserved in all polychronia, even in that of the Helsinki diocese. However, the possibility to include "and sisters" in the epistle readings has been included. ${ }^{23}$

\section{How does the Theotokos save us?}

In Finland, where the majority of the population has been Lutheran, the reverence shown to the Theotokos, a characteristic element of Orthodox spirituality, has caused confusion, and a common mocking name both for Roman Catholic and Orthodox is, even today in some circles, "worshippers of Mary". ${ }^{24}$ The petition "Most-holy Theotokos, save us" (Y

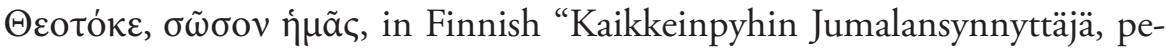
lasta meidät") is a frequent formula in both personal prayers and liturgical patterns of the Eastern Orthodox Church.

In order to explain this view, Archbishop Paul of Karelia and all Finland (1914-1988) promoted a change to the formula, adding the word "through your intercessions" (in Finnish: "esirukouksillasi", which is etymologically formed by the prefix esi-, "on behalf of someone", rukouksillasi, "through your prayers"). It is unclear when this addition was first introduced: it is not included in standard service books, and the lack of documentation makes tracing the roots of the addition difficult. ${ }^{25}$ Surprisingly enough, in the parish of Ilomantsi, which used to be a laboratory for Archbishop Paul's liturgical experiments, ${ }^{26}$

\footnotetext{
21 In 2016-2017, I have attested to the use of this formula at least in the churches of Ascension (Tikkurila, Vantaa), St Herman of Alaska (Tapiola, Espoo), and Sts Alexander Nevsky and John Chrysostom (Hämeenlinna).

22 Most importantly Uspensky Cathedral (Helsinki), but also most other churches of the Helsinki parish.
}

23 Jumalallinen liturgia, Porvoo, Ortodoksisen kirjallisuuden julkaisuneuvosto 2011, p. 137-139 and p. 376.

24 An interesting on-going research project on the Finnish Orthodox women's views on the Theotokos is conducted by professor Elina Vuola at the University of Helsinki; see, for example, Elina Vuola, "Finnish Orthodox Women and the Virgin Mary", in: Journal of the European Society of Women in Theological Research 24 (2016), p. 63-80.

25 Private conversation with Makarios Lehtimäki, former secretary and deacon of Archbishop Paul, on 27th February 2017.

26 The liturgical renewals of Archbishop Paul have received some scholarly attention, but have not been studied thoroughly. Doctoral candidates Timo Hirvonen and Maria Verikov are preparing studies on this subject, the former from the point of view of church politics, 
this addition was never employed, ${ }^{27}$ but it is still in use in some places, for example the parish of Hämeenlinna. ${ }^{28}$

Metropolitan John of Helsinki, later on the Archbishop of Finland and, before his death, Metropolitan of Nicaea, responded to Paul's addition. It is known that Paul's and John's relations were not particularly warm, but in any case, John seems to be correct in his worry about the addition. In a talk published in the national Finnish Orthodox magazine Aamun Koitto in 1973, he suggests the following (the English translation is by the author of the paper). He does not refer exclusively to this formula, but he discusses

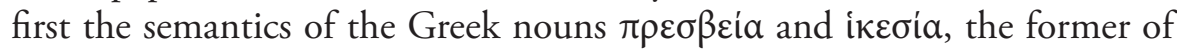
which corresponds to the Finnish addition "esirukouksillasi". In the latter part of the talk he discusses the semantics of the Greek verb $\sigma \omega \zeta \omega$, "to save", as opposed to the Finnish equivalent "pelastaa":

Presvia, which is translated as intercession, means actually, in its most ancient meaning, dignity (especially dignity related to an old age), embassy, an ensemble of ambassadors, i.e. a group of ambassadors, and in a metaphorical way, intercession. The root verb actually means to be older, to be the eldest in something [...] We understand that actually all this is included in the intercession delivered by saints. It is representing, being an ambassador, delivering a message, saying something in a dignified way, exposing something with the wisdom brought by an old age, etc. [...] In very many prayers the Theotokos is a person, from whom "presvia", acting as an ambassador, is asked. In certain occasions it seems that it should be maybe translated in another way than "intercession". In a way, it would bring forth more clearly, how broadly the Orthodox spiritual experience understands particularly the Theotokos' influence and significance as our advocate, our representative near the throne of God [...] In many occasions different saints, most importantly the Theotokos, are asked that they would save us with their fervent supplications. Here we have another difficult problem. The Greek verb, that we translate as "save" is, in its basic sense, much broader and means, for example, to provide protection, to protect. [...] In Finnish, the verb "to save" has received, as a theological term, a narrow and particular meaning. I reckon that

and the latter from the point of view of church music. Unfortunately for the wider public, most of these publications are in Finnish.

27 Private conversation with Fr Vesa Takala, former priest of the Ilomantsi area, on 23rd February 2017.

28 I grew up myself in the parish of Hämeenlinna and took part actively in church services from 2000 to 2006 . This was the formula that was used in our services without exception. 
in the context of these prayers using that translation can be sometimes theologically misleading. If it was translated "protect us", "provide protection", it would be a more correct rendering: be our protector through your intercessions. "To save" leads our thoughts perhaps to the salvific work of Christ. ${ }^{29}$

Metropolitan John's suggestion to replace Paul's proposal "save us through your intercessions" with "protect us" did not actualize in the liturgical practice. John's explanation of the verb "to save" could also be blamed as insufficient: in addition to her intercessions (or "being an advocate", as John would perhaps prefer), the Theotokos also saved the humanity through giving birth to Christ. Eventually, neither Paul's nor John's suggestion to change the formula "Most-Holy Theotokos, save us", came to substitute the traditional Finnish translation "Kaikkein pyhin Jumalansynnyttäjä, pelasta meidät".

\section{Who is "our bishop"?}

A recent controversy took place on March 1, 2015, when Metropolitan Ambrose of Helsinki was serving a liturgy at his cathedral of the Dormition (Uspensky) in the Finnish capital. Present at the service was also the (female) bishop of the local Lutheran diocese, Irja Askola. During the ceremony of the ordination of a new priest, Ambrose invited Askola to observe the ceremony inside the altar space. This caused an international scandal, leading finally not only to a complaint by Archbishop Leo of Karelia and all Finland, the head of the autonomous church, but also to an official warning to Metropolitan Ambrose from the Holy Phanar. The matter was widely discussed not only in the Finnish press, but also in international Orthodox media: most documentation about the issue is published online.

However, it is noteworthy that the news articles written on the subject mention only rarely an addition in the petitions read by the deacons in various parts of the liturgy. After commemorating "our Metropolitan Ambrose", he continued by reciting "and our Bishop Irja". This had taken place also before the liturgy in question. ${ }^{30}$ Archbishop Leo of Karelia and all Finland mentioned this also in his declaration on March 3, 2015:

The Lutheran bishop of Helsinki, Irja Askola, took part in the liturgy last Sunday, served by Metropolitan Ambrose. She observed the priest's ordination that took part in the liturgy in the altar of

\footnotetext{
29 Metropolitan John, "Pyhien esirukouksista", in: Aamun koitto 19/1973, p. 250-251.

30 Apart from the short mention in the article in "Simeon ja Hanna", the practice of commemorating Askola has not been documented elsewhere; however, I have myself been present in divine services at the Uspensky Cathedral in 2014 and 2015 where her name was commemorated in the formula "our bishop".
} 
the Uspensky cathedral. Additionally, the deacons read petitions for "Bishop Irja" and "our Bishop Irja".

Both customs are against the liturgical order of the Orthodox Church. The Orthodox Church in Finland is dogmatically, canonically and liturgically a part of the Ecumenical Patriarchate. We follow the liturgical order of our patriarchate and other local Orthodox churches in everything.

In Finland, in the relations between churches, we follow the recommendation for good behaviour accepted by us in the ecumenical council on October 15, 2002: "we respect the member churches' right for dogmatical differences, different customs of prayer, differences in liturgical traditions and forms of spiritual life."

The members of our churches have primarily an Orthodox and only thereafter Finnish identity. This is also the starting point of the ecumenical communication between the churches. In the Orthodox Church, the critical evaluation of our own tradition happens always outside the sacred space. Arbitrary changes in the liturgical order, or improvising [liturgically], is ecumenical populism, in which we do not take part. ${ }^{31}$

This comment includes some problematic points. Firstly, Archbishop Leo does not provide a more extensive explanation why commemorating Bishop Irja is problematic from an ecclesiological point of view. Secondly, it can be questioned, whether or not observing a priest's ordination in the altar is related to liturgical order. Thirdly, the assumption made on how the members of the church experience their identity primarily as Orthodox and only secondarily as Finnish, is not based on any factual evidence: no such studies have been conducted.

The Archbishop submitted the case to the Holy Synod of the Ecumenical Patriarchate, which answered to the plea with a warning to Metropolitan Ambrose not to repeat such actions: otherwise the Holy Synod would impose a canonical punishment. ${ }^{32}$

Our task here is not to provide details regarding Irja Askola's presence in the altar: instead, we shall concentrate on her commemoration as "our bishop". Metropolitan Ambrose wrote an explanation to the main Finnish newspaper, "Helsingin Sanomat", on March 14, 2015. He mentions only vaguely the

\footnotetext{
31 http://www.ort.fi/uutiset/arkkipiispan-tiedote, viewed on 27th February 2017.

32 http://yle.fi/uutiset/3-8081965. The synod's decision was mainly concerned with the presence of Irja Askola in the altar: see also http://www.hs.fi/kotimaa/art-2000002832504. html, viewed on 27th February 2017.
} 
matter of commemoration, but the motive for the treatment of Askola in the liturgy was generally described as a sign of openness between the two churches. ${ }^{33}$ the addition "our Bishop Irja", he provided the following explanation:

I can say that this was not an instruction given beforehand, I had not told the deacons to pray or not to pray for Irja. They made it up themselves, and of course we know the motive behind it. Sometimes, when Irja has been here in Sofia [the diocesan centre] in a meeting and when she was sick, we prayed for her in this petition. And when the deacons saw that Irja was on the kleros [the elevated space in front of the iconostasis], they prayed for her, too. I don't complain about it, even though it was an exception to the normal practice. And, in any case, petitions are intercessions on behalf of someone, we pray for the president of the country, for prisoners, for travellers, for the sick, and so on. But in the Great Entrance, there we commemorated only Archbishop Leo, I did not commemorate Irja - and in the consecration of the Holy Gifts only the Archbishop and I were commemorated. Because it is the centre of the Church's life.

Based on this comment, it is clear that Metropolitan Ambrose was not opposed to the addition, even if he was not responsible for adding it: in another interview, he described that the deacons acted "in the guidance of the Holy Spirit", ${ }^{34}$ a statement that caused the Archbishop to oppose by saying "neither do the talks about the Spirit's guidance belong to the realization of the liturgical order of the Orthodox church or Her faith - the Orthodox church is not a charismatic awakening movement or a part of Pentecostals" ${ }^{35}$ However, he does not comment on the word "our bishop". Elsewhere Metropolitan Ambrose implies that the Orthodox Church could accept Lutheran priesthood: "Our

33 http://www.hs.fi/mielipide/art-2000002808409.html, viewed on 27th February 2017. In this paper, there is a mistake in argumentation: Metropolitan Ambrose claims there is no canon that forbids women from entering the altar. Archbishop Leo draws up canon 44 of Laodicea, which is explicit in forbidding women from entering the altar: https://simeonjahanna.com/2015/03/14/arkkipiispa-leo-suomen-ortodoksinen-kirkko-ei-ole-irrallinensaareke/, viewed on 27th February 2017. Elsewhere, Metropolitan Ambrose states that "we cannot eternally discuss the validity of canons created in another era, and they are neither universal rules, especially since they are not the core of the Church's life, but practical issues", https://simeonjahanna.com/2015/03/15/metropoliitta-ambrosius-avointa-ekumeenisuuttaja-vuorovaikutusta/, viewed on 27th February 2017.

34 https:/www.kotimaa24.fi/artikkeli/arkkipiispa-leo-rikottu-koko-ortodoksista-maailmaavastaan/?katselukoodi $=53934290 \mathrm{c} 97 \mathrm{ff} 4 \mathrm{~d} 0 \mathrm{~d} 13 \mathrm{e} 618 \mathrm{cc} 2 \mathrm{a} 2 \mathrm{ce} 97 \mathrm{fe} 09 \mathrm{~b} 28594562 \mathrm{c} 76 \mathrm{dcc} 5 \mathrm{c}-$ 84ce40f86cf, viewed on 27th February 2017.

35 https://simeonjahanna.com/2015/03/14/arkkipiispa-leo-suomen-ortodoksinen-kirkkoei-ole-irrallinen-saareke/, viewed on 27th February 2017. 
church has never decided, that the ministry of the Lutheran church would not be a real ministry. Nor have we decided, that it would be [a real ministry]." 36

It is characteristic that he uses the word "ministry" (in Finnish: "virka"), a term more often used in a Protestant rather than an Orthodox context, where "priesthood" (in Finnish: "pappeus") is preferred. Metropolitan Ambrose sees this also a question relating to female priesthood. He claims that "in the Orthodox world, there is a certain phobia against feminism. Female priesthood is feared, even though it remains an open question in the Orthodox Church. We have never taken the position of ever having female priests". ${ }^{37}$ This implied feminist emphasis is apparent in the liturgical encyclical sent by Metropolitan Ambrose in 2009, quoted above, in which more gender-neutral expressions are preferred.

The comments mentioned in the previous paragraph are diplomatic, but imply a positive attitude towards both questions. However, in regarding the level of heresy of the Roman Catholic and the Lutheran church, Metropolitan Ambrose is rather explicit: "I do not believe either that enlightened Orthodox believers, in different parts of the world - those who are well informed and ponder upon things - would today believe, that the Catholic church or the Lutheran church would be somehow heretic. People do not think like this. At least I do not think like this." ${ }^{38}$ This is a rather daring implication, according to which considering the Catholic or Protestant church heretic in any way does not either exist or, if it does exist, is the model of thought of some kind of illiterate or ignorant, non-enlightened Orthodox believers. It is not our task here to evaluate whether or not Protestants and Catholics should or should not be considered heretics, but certainly opinions of both sides exist among Orthodox believers: this was one of the most debated issues of the Great and Holy Synod of the Orthodox Church in 2016.

\section{Conclusion}

We have now seen three different cases of additions or omissions in liturgical texts. Our task now is to reflect, even breafly, the reasons behind

\footnotetext{
36 https://simeonjahanna.com/2015/03/15/metropoliitta-ambrosius-avointa-ekumeenisuutta-ja-vuorovaikutusta/, viewed on 27th February 2017.

37 http://www.hs.fi/kotimaa/art-2000002832663.html, viewed on 27th February 2017. Researcher Jussi Sohlberg from the Research Institute of the Evangelical-Lutheran Church of Finland claims sex was a definitive issue in the disagreement between Metropolitan Ambrose and Archbishop Leo: if the Bishop had been a man, the scandal would not have been so radical. https://suomenkuvalehti.fi/jutut/kotimaa/naispiispa-saattoi-olla-sietamaton-niitti-ortodoksien-riidan-syy-taustat/?shared=72546-c82fafc9-999, viewed on 27th February 2017.

38 https://simeonjahanna.com/2015/03/15/metropoliitta-ambrosius-avointa-ekumeenisuutta-ja-vuorovaikutusta/, viewed on 27th February 2017.
} 
these changes. A more thorough study would require an extensive research in the form of interviews: interviewing Archbishop Paul is impossible, but several persons close to him are still alive. In the lack of such study, I shall now present some hypotheses regarding the motives behind these changes.

In the first case, Metso and Sundkvist hypothesize that the commemoration of "all Christians" in the Great Entrance is caused by the oppressive post-war atmosphere. I find this thought tenable, but perhaps not in the sense of "pleasing" the Lutheran majority: in the end, the amount of non-Orthodox present in the church space is rather small compared to the Orthodox participants. Instead, I suggest the need to add such changes is to calm the consciousness of the Orthodox population with their co-existence with the Lutheran majority: for most believers, the social circles consist mainly of non-Orthodox, especially since after the wars most marriages are mixed (i.e. between a Lutheran and an Orthodox). ${ }^{39}$

Another factor in these dynamics are the increasing numbers of converts. The question of praying for "all Christians" could be assumed to be a way for converts to pray for their non-Orthodox family members and friends, while Archbishop Paul's addition "through your intercessions" explains the Mariological dimension of Orthodox worship, something that is not at all prominent in the Finnish Lutheran tradition. The addition was, actually, a commentary of a liturgical text inside the liturgical text itself: such additions, however, do not belong to the tradition of Orthodox liturgical texts (commentaries were always written as separate treatises), and perhaps because of this the addition did not become popular.

These changes in liturgical texts are probably done with no intentions to disrespect traditional Orthodox ecclesiology of the Church as a community that shares a common faith and, therefore, common eucharistic chalice. However, I dare to suggest that there is a certain boost in the "ecumenical" changes in liturgical texts in the $21^{\text {st }}$ century, implied by the liturgical publications of those years, but mostly promoted by Metropolitan Ambrose, and these changes are more problematic from an ecclesiological point of view.

Both Metropolitan Ambrose's encyclical in 2009 and the scandal around Bishop Irja Askola's commemoration in liturgies, as well as his open rejection of a part of the canonical tradition of the Church as useless for the modern Orthodox Church, express a change towards the recognition of the Evangelical Lutheran church of Finland as a sister church whose hierarchy and priesthood is fully recognized. Ecclesiologically, the addition

\footnotetext{
39 The problems of mixed marriages has been discussed by Pekka Metso in his "Ortodoksisen uskontokasvatuksen tutkimuskenttä: Uskontokasvatus murroksessa?”, http://www. kasvatus-ja-aika.fi/site/?lan=1\&page_id=694, viewed on 27 $7^{\text {th }}$ February 2017.
} 
"our bishop" is, perhaps, the most radical of all the discussed cases. It poses several questions: is the sacrament of priesthood valid outside the Orthodox Church? Is Lutheran priesthood sacramental at all? ${ }^{40}$ Even if Lutheran priesthood was considered sacramental and valid by the Orthodox Church, would not there be a controversy since Askola is a woman and the Orthodox Church does not accept female priesthood? And, finally: how would a bishop of a denomination separate from the Orthodox Church be called "our bishop" by the Orthodox faithful, if there is no communion between the two churches? It must be emphasized that this scandal seems rather one-sided: Bishop Irja Askola, herself, has not commented on the scandal for the press at all.

I fully agree that in a country such as Finland, where most of the Orthodox do not live in purely Orthodox surroundings, it is important to provide a possibility to also pray for their non-Orthodox brothers and sisters liturgically. Additionally, keeping positive relations with the predominant religion is vital for the Orthodox minority. However, such ideas should not affect the traditional Orthodox liturgical texts without proper theological consideration. All three cases discussed in this paper have proved to be problematic in their ecclesiological or dogmatic sense: a proper solution, therefore, still awaits its finder.

40 Different opinions regarding Lutheran priesthood have been presented. The Apologia Confessionis (chapter XIII) by Philipp Melanchton from 1531 claims there is no sacramental priesthood in the Lutheran Church as such, even though it could be called sacramental if this means the practice of teaching the Word and distributing sacraments. 